\title{
Utilization of mucilage extracted from taro tubers (Colocasia esculenta) in canned beef
}

\author{
Sh. A. Hozifa *, S. M. El Dousky and R. H. Salem \\ Food Science and Technology Department, Faculty of Home Economics, Al-Azhar University, Nawag, Tanta, \\ Egypt
}

*Correspondence: shaymaaabdelhamedhozifa@azhar.edu.eg (SH. Hozifa)

\section{ABSTRACT}

The commercial gelatin is not accepted from some Muslim community because it might be extracted from pig. This issue led to searching for alternative gelatin sources. This study aims to investigate the possibility of utilization of natural binders extracted from plant sources such as mucilage extracted from taro (Colocasia esculenta) as an alternative gelatin in different concentrations (1,2 and $3 \%$ ) in canned beef products. In this study we evaluated the physical properties, minerals $(\mathrm{K}, \mathrm{P}, \mathrm{Na}, \mathrm{Ca}, \mathrm{Zn}, \mathrm{Pb}$ and $\mathrm{Cd})$, antioxidant activity and total phenolic for taro mucilage. Chemical quality characteristics, texture profile, microbiology analysis and sensory evaluation were evaluated in the canned beef products. The comparison study between taro mucilage treatments and commercial gelatin showed the taro mucilage $\left(\mathrm{TM}_{2}\right)$ had a higher value of emulsion capacity (35.71 g water/g sample) and oil absorption (2.84 $\mathrm{g}$ oil/g sample) than gelatin ( $14.28 \mathrm{~g}$ water $/ \mathrm{g}$ sample), ( $0.8 \mathrm{~g}$ oil $/ \mathrm{g}$ sample); respectively. Water absorption values were higher in the commercial gelatin $(37.80 \mathrm{~g}$ water/g sample), compared to the taro mucilage treatments $\left(\mathrm{TM}_{1}, \mathrm{TM}_{2}\right.$ and $\mathrm{TM}_{3}$ ) that were $23.48,24.28$ and23.20g water/g sample, respectively. Viscosity value was higher in taro mucilage treatment $\left(\mathrm{TM}_{2}\right)(625 \mathrm{cp})$ compared to the other all treatment. The total phenolic content in taro mucilage was $32.2 \mathrm{mg}$ gallic acid/g). In conclusion, adding hydrocolloid material (taro mucilage) to canned meat improved the stability of the samples during storage at room temperature for six months. On the other side, this material improved the texture profile, and organoleptic properties of canned beef.

Keywords: Taro mucilage; Texture profile; Quality attributes; Meat products.

\section{INTRODUCTION}

Canned beef is referred to $\backslash$ a meat product in closed sterilized cans (USDA, 2003) as reported by Hamasalim (2012). Hydrocolloids are a large group of food additives with international applications in the food manufacture also are high-molecular-weight biopolymers and obtained by extraction from plants and sea plants (Dickinson, 2003). Binder materials are divided into two main types: natural binders and artificial binders. A commonly used artificial binding agent is CMC (Carboxy Methyl Cellulose) is very costs, it is considered non economical (Syamsu, 2007). Taro Mucilage has unique rheological properties and gives much potential for use as a food binder and stabilizer, in addition to producing gelling properties and increases viscosity (Njintang et al., 2011; Kaushal et al., 2013).

Haug and Draget (2009) reported that for Muslims, the religion is the reason for not accepting gelatin from pig sources and beef gelatin is accepted if it has been slaughtered according to religious basics and requirements. The aim of this study to use natural binders from plant sources in canned meat, where there are few studies on the use of gelatin alternatives from plant sources in canned meat, so it was determine the optimal conditions for mucilage extracted from taro. Descriptive tests were determined to identify the most important functional groups and physical tests in taro mucilage. Also, the effect of the taro mucilage on the chemical quality attributes, texture and microbiological quality of canned meat product during storage at room temperature for six months.

\section{MATERIALS AND METHODS}

\section{Materials}

Taro (Colocasia esculenta) was purchased from local market, Tanta City, El-Gharbia Government, Egypt.

Raw beef meat and beef fat used in this study was purchased from butcher's shop, Tanta City, El-Gharbia Government, Egypt.

Salt, sugar, garlic powder and black pepper were purchased from local market, Tanta City, El-Gharbia Government, Egypt.

Chemical compounds, like sodium nitrite were purchased from Al-Gomhoria Company, Tanta City, El-Gharbia government, Egypt.

Tin cans were purchased from Kaha Company for Preserved Food, Kaha city, ElQalyubiyah Government, Egypt. It's 
approximetly dimensions are $53 \mathrm{~cm} 3$ and have a capacity of $160 \mathrm{~g}$.

\section{Extraction of taro mucilage}

Taro mucilage was extracted according to the method described by Arora et al. (2011) with some modifications. Fresh taro corms were washed with tap water, peeled and sliced. The cubic pieces soaked in 1:3 and 1:5 (W/V) of distilled water. Heating at $50{ }^{\circ} \mathrm{C}$ for $2 \mathrm{~h}$, and soaked in $1: 7(\mathrm{~W} / \mathrm{V})$ of distilled water. Let to stand for half an hour followed by heating at 80 ${ }^{\circ} \mathrm{C}$ for $2 \mathrm{~h}$.

The extract (Taro mucilage) was filtered through muslin cloth to obtain mucilage. Three volumes of ethyl alcohol $95 \%$ were added to one volume of the supernatant to precipitate mucilage. The mixture was centrifuged (K2015R, T10A, United Kingdom) by 4000 rpm at $4^{\circ} \mathrm{C}$ for $10 \mathrm{~min}$. The mucilage was dried in an electric oven (XBC605, UNOX, Italy) at $40^{\circ} \mathrm{C}$. The dried sample was ground to fine powder in an electric grinder using a disc mill (Moulinex, made in France), sieved through 50 mesh and stored at $5 \pm 2^{\circ} \mathrm{C}$ for further use.

\section{Preparation of canned beef}

Canned beef was preparation according to EOS (2013), at Kaha Company for preserved food, Kaha city, El- Qalyubiyah government, Egypt. Raw beef meat was washed, cut and then chopped. The fat percentage was adjusted to be $20 \%$ in the final product. Chopped meat was mixed with salt, sugar, garlic powder, black pepper and sodium nitrite 2.5, 1.5, 1.5, 0.5 and $0.02 \%$, respectively, by processor (Moulinex, made in France). Gelatin added by $3 \%$ to the control canned beef. Taro mucilage was added by replacement of gelatin in proportions at ratio (gelatin: taro mucilage 3:0, $2: 1,1: 2$, and $0: 3 \%$ respectively). The mixture was packaged in tin cans.After packaging, the exhausting (preheating at $77^{\circ} \mathrm{C}$ ) and double seaming were made and sterilization at $121^{\circ} \mathrm{C}$ for $20 \mathrm{~min}$, and cooling for $15 \mathrm{~min}$. Following that, the cans incubation at $55^{\circ} \mathrm{C}$ for 10 day. Finally, the samples were stored at ambient temperature and analyzed periodically every two months for six months (zero time, two, four and six months).

\section{Analytical methods}

\section{Physical characteristics}

\section{Swelling index}

Swelling index procedure was determined according to the method recommended by Pharmacopoeia (2008).

\section{Water absorption}

Water absorption was carried out in comply with the Chau and Cheung (1998), as reported by Thanatcha and Pranee (2011). The samples were weighed $(0.25 \mathrm{~g})$, added with $25 \mathrm{ml}$ distilled water, and mixed by magnetic stirrer for $15 \mathrm{~min}$, and then centrifuged (K2015R, T10A, United Kingdom) at $3500 \mathrm{rpm}$ for $30 \mathrm{~min}$.

\section{Oil absorption}

Oil absorption of the tested samples was estimated according to Raghavendra et al. (2006).

\section{Emulsion capacity (EC)}

Emulsion capacity of the tested samples was determined as described by Obatolu et al. (2001). The samples were weighed $(1.0 \mathrm{~g})$, dissolved in $50 \mathrm{ml}$ distilled water, and added 50 $\mathrm{ml}$ refined oil (corn oil). Then, homogenizing for $1 \mathrm{~min}$ and centrifuged (K2015R, T10A, United Kingdom) at $1500 \mathrm{rpm}$ for $5 \mathrm{~min}$. (Thanatcha and Pranee, 2011). Finally, measured the height of emulsified layer compared with the height of whole layer.

\section{Minerals content of taro mucilage and commercial gelatin}

Dried sample $(0.5 \mathrm{~g})$ was digested using the hydrochloric acid as described by (Jones et al. 1991).

\section{Total Phenolic Content of Taro Mucilage:}

Phenolic compounds were determined based on a method described by Singleton et al. (1999), as reported by Mohamed et al. (2010).

\section{Antioxidant activity of taro mucilage}

\section{Determination of radical DPPH scavenging activity}

The free radical scavenging activity of tested samples was measured according to the DPPH method as reported by Nanjo et al. (1996).

\section{Determination of ABTS scavenging activity}

The ABTS assay of tested samples was measured according to the method of Re et al. (1999).

\section{Texture profile of canned beef}

Texture Profile Analysis (TPA) of all tested samples were determined according to the method of Bourne (2003).

\section{Microbiological examination of canned beef}

\section{Samples preparation}

Samples were prepared using the recommended methods for the microbiological 
examination of foods published by American Public Health Association (A.P.H.A., 1976).

\section{Total viable bacterial counts}

Total viable bacterial count of the tested samples were determined by transferring appropriate dilution into a sterile plates and pouring with Nutrient Agar Medium (Difco, 1984).

\section{Total coliform bacterial counts}

Total coliform count of tested samples was determined on Macconkey Agar Media according to the method of Oxoid (1992).

\section{Proteolytic bacterial counts}

Proteolytic bacterial count of the tested samples was determined according to Hamasalim (2012).

\section{Lipolytic bacterial counts}

Lipolytic bacterial count of the tested samples was determined according to Hamasalim (2012).

\section{Total spore forming bacterial counts}

Enumeration is carried out for bacteria belonging to species of Clostridium and Bacillus, were determined according to Hamasalim (2012).

\section{Mould and Yeast Counts}

Moulds and yeasts count of the tested samples was determined according to Difco (1984).

\section{Sensory Evaluation of Canned beef}

Sensory evaluation of canned meat samples was carried out by10 panelists from Food Science and Technology Depatment, Faculty of Home Economics, Al-Azhar University, Tanta, Egypt (Smith et al., 1973).

\section{RESULTS AND DISCUSSION}

\section{Physical characteristics of taro mucilage and commercial gelatin}

Water absorption for taro mucilage treatments has been shown in Table (1) which observed that the value of $\mathrm{TM}_{2}$ (24.28 $\mathrm{g}$ water/g dry sample) was higher than $\mathrm{TM}_{1}$ and $\mathrm{TM}_{3}$, which were 23.48 and $23.20 \mathrm{~g}$ water/ g dry sample weight while, commercial gelatin (CG) was found to be $37.80 \mathrm{~g}$ water/g dry sample weight; respectively.

Also, data in Table (1) showed that the values of water absorption were higher in commercial gelatin than mucilage extracted from taro. These results were higher than value of water absorption for Jujube mucilage powder which was $11.77 \mathrm{~g}$ water/g dry sample weight. While these results were lower in water absorption for Ocimum canum S. seed, which was $157.09 \mathrm{~g}$ water/ g dry sample weight (Thanatcha and Pranee, 2011).

Hong and Ibrahim (2012) cites by Naqvi et al. (2010) indicated that high concentration of hydroxyl groups in polysaccharide had high potential for water binding and was capable of absorbing significant amounts of water. From the same Table the swelling index values of taro mucilage treatments are showed that the $\mathrm{TM}_{2}$ sample had the higher value $(340 \%)$ than $\mathrm{TM}_{1}$ and $\mathrm{TM}_{3}$, which were recorded 322 and $317 \%$, respectively. While commercial gelatin (CG) swelling index value was $380 \%$.

In addition the values of swelling index were higher in commercial gelatin than from taro mucilage. Our results were agreement with Assi et al. (2017) who found that the mucilages extracted from fruit of B. manni (Sran) and leaves of C.oiltorius (Kpllala), fruit of $I$. Gabonensis (Kplé) and A. esculentus (Okra) provided hydration capacities ranging from 257.39 to $519.52 \%$.

The emulsion capacity value in mucilage extract $\left(\mathrm{TM}_{2}\right)$ which was recorded $35.71 \%$.was higher than that found in the other tested samples, while the lowest value was found in mucilage extract $\left(\mathrm{TM}_{3}\right)$, which was recorded $27.14 \%$,compared with the emulsion capacity value for commercial gelatin (CG) which was $14.28 \%$.

From previous results taro mucilage has the highest values in emulsion capacity, compare with commercial gelatin. Our results are partially agree with (Thanatcha and Pranee, 2011) who found that the EC. for Jujuba mucilage powder was $52.22 \%$. Andrade et al. (2015) reported that the chemical composition provides that the emulsifying power of the TM (Taro mucilage) can occur due to the presence of carbohydrates (hydrophilic part) together with the small protein fraction, also its conformation and the presence of amino acids with hydrophobic radicals. The lipid fraction may help in emulsification, however its content is low, and the gums usually do not contain lipids.

The oil absorption amounts for taro mucilage treatments and commercial gelatin also showed in the same Table (1), it present that the highest value of oil absorption for taro mucilage treatments was detected in $\mathrm{TM}_{2}(2.84 \mathrm{~g}$ oil/g dry sample), respectively and the lowest value was $\mathrm{TM}_{3}$ (2.24g oil/g dry sample). While, 
oil absorption values for gelatin (CG) was $(0.8 \mathrm{~g}$ oil/g dry samples). Thebaudin et al. (1997) reported that oil absorption is the ability of absorption on sample surface. Mucilage had high oil absorption value since many nonpolar mucilage molecules can trap large amounts of oil particles.

From tabulated data taro mucilage has the highest values of oil absorption compared with the commercial gelatin sample.

\section{Minerals composition of taro mucilage and commercial gelatin}

Some important minerals of taro mucilage and commercial gelatin were determined and presented in Table (2).

Table (2) illustrated that taro mucilage (TM) content of calcium, magnesium and sodium were $84.30,54.10$ and $46.12 \mathrm{mg} / 100 \mathrm{~g}$, respectively. While commercial gelatin was contained $602.50,128.27$ and $127.70 \mathrm{mg} / 100 \mathrm{~g}$ for $\mathrm{Ca}, \mathrm{Na}$ and $\mathrm{Mg}$, respectively. The mucilage usually appears as calcium salts which have a significant effect on the capacity to hold water and other biophysical properties (Matsuhiro et al., 2006).

Also data in the same Table (2) are showed that K, P and Mn recorded 15.62, 2.10 and 0.065 $\mathrm{mg} / 100 \mathrm{~g}$ in commercial gelatin sample (CG), while they were presented 36.50, 0.112 and $1.63 \mathrm{mg} / 100 \mathrm{~g}$ in taro mucilage sample; respectively.

This characteristic of minerals may be used to overcome the deficits of certain minerals such as $\mathrm{Mg}, \mathrm{Ca}$ and $\mathrm{Zn}$ whose deficiency causes anemia and threatens the vital prognosis of the mother and child as indicated by Avallone et al. (2003). Data presented in the same Table show that the concentrations of zinc, cadmium and lead achieve lower value compared to the other above mentioned minerals.

Metal ions are bound by several ionic or covalent attachments, with the metal ion occupying a central position in the structure. For example, high divalent cations such as $\mathrm{Ca}$ may form bridges between neighboring carbohydrate molecules resulting in gel formation as reported by John (1999). Also, according to Sagou (2008) sodium will increase viscosity as reported by Assi et al. (2017).

(GMIA, 2012) Gelatin Manufacturers Institute of America indicated that content of gelatin minerals sodium $(\mathrm{Na})$, phosphour, calcium $(\mathrm{Ca})$, potassium $(\mathrm{K})$, lead $(\mathrm{Pb})$ and zinc (Zn) were 500, 1, 90, 125, 0.002 and 1.5 ppm, respectively.

\section{Antioxidant activity and total phenolic content of taro mucilage}

The antioxidant activity of taro mucilage treatment was determined on the basis of the DPPH and ABTS radical scavenging activity.

The obtained results are showed in Fig (2) the taro mucilage has an antioxidant activity, which was $3.368 \mathrm{mg}$ AAE/g, by DPPH radical scavenging. In regards to the ABTS radical scavenging activity, it was $9.063 \mathrm{mg}$ TE/g of taro mucilage(TM). Total phenolic content in taro mucilage was $32.2 \mathrm{mg}$ as Gallic acid/g. From figure data, the antioxidant activity and total phenolic contents don't measure in commercial gelatin; this is may be due to the gelatin has higher percentage of protein.

The DPPH and ABTS radical scavenging activities were examined to evaluate the ability of the polysaccharide fractions to provide hydrogen to a free radical. This activity may be due to the amount of phenolic compounds found in raw materials (Skyberg et al., 2012).

Kim et al. (2019) measured anti-oxidant activity in steamed and un- steamed taro corm extracts by DPPH which was recorded 34.82 and $24.37 \%$ respectively, while the value of ABTS activity was 56.34 and $42.33 \%$ of steamed and un- steamed taro corm extracts respectively. Also, they found that total phenolic content in steamed and un- steamed taro corm extracts was 42.77 and $32.32 \mathrm{mg}$ GAE/g on dry weight; respectively. Nguimbou et al. (2012) found that total phenolic content in taro mucilage ranged from 28.0 to $35.4 \mathrm{mg}$ ferulic acid equivalent/g. Polyphenols are bioactive substances widely distributed in natural products (Duthie et al., 2000).

Chemical quality attributes of canned meat supplements with different levels of taro mucilage (TM) as compared by commercial gelatin (CG).

Data in Table (3) cleared that free fatty acid (FFA) value in control sample was 0.065 , while canned meat samples treated with taro mucilage showed the lowest value compared to samples containing gelatin, this is may be due to taro mucilage has an antioxidant activity as shown in Fig (1). From tabulated data, the peroxide value $(\mathrm{PV})$ and thiobarbtioric acid (TBA) for control sample of canned meat was 0.52 meq. $\mathrm{O}_{2} / \mathrm{Kg}$ and $0.271 \mathrm{mg}$ malonaldhyde $/ \mathrm{kg}$, respectively. While sample treated with taro mucilage $\left(\mathrm{T}_{3}\right)$ (canned beef contained 3\% taro mucilage) has the lowest value for $\mathrm{PV}$ and TBA which were 0.24 meq. $\mathrm{O}_{2} / \mathrm{Kg}$ and $0.142 \mathrm{mg}$ malonaldhyde $/ \mathrm{kg}$ 
respectively at zero time, compared to control sample. When the canned meat samples were stored for six months at ambient temperature, the samples treated with high percentage of taro mucilage recorded a slight increase in the of FFA, PV and TBA values which ranged from 0.033 to $0.042 \%, 0.24$ to 0.32 meq. $\mathrm{O}_{2} / \mathrm{Kg}$ and 0.142 to $0.159 \mathrm{mg}$ malonaldhyde $/ \mathrm{kg}$, respectively compared to the control sample.

From the same table, the value of TVB-N for canned meat samples containing high percentage of taro mucilage $\left(\mathrm{T}_{3}\right)$ decreased significantly $(3.26 \mathrm{mg} / 100 \mathrm{~g})$ compared to control sample $(3.72 \mathrm{mg} / 100 \mathrm{~g})$ at zero time. The increase in TVN value is also noticed in samples stored at room temperature for six months. The $\mathrm{pH}$ values has been observed in the same Table (3), which found that the samples containing taro mucilage are nearly to the $\mathrm{pH}$ value of canned meat sample. On the other hand, during storage, a slight decrease in the $\mathrm{pH}$ values of all parameters observe due to the effect of nonsignificant increase in the acidity values.

From these results (Table3), it could be found that the samples containing a high percentage of taro mucilage (T3) (canned beef contained $3 \%$ taro mucilage) have been recorded the least values of all previous parameters even after two months during the storage periods. Our results were in the line with those reported by Hamasalim (2012) which determined FFA, PV and TBA for corned beef and found the initial values were ranged from 0.03 to $0.065 \%$ FFA, 0.60 to $0.92 \mathrm{meq} \mathrm{O} / \mathrm{kg}$ fat PV and $1.35 \mathrm{mg}$ malonaldehyde $/ \mathrm{kg}$ fat.

Furthermore, it was observed that the sample was agreement with results obtained by Ebeed et al. (2015) which was $2 \mathrm{mg}$ TBA. They evaluated the total volatile nitrogen in canned meat with a mean value $10.88 \mathrm{mg} / 100 \mathrm{~g}$. In addition, measured the $\mathrm{pH}$ value of canned beef samples and found that the mean value was 6.11 .

Texture profile of canned meat supplemented with different levels of taro mucilage (TM) as compared by commercial gelatin (CG)

Texture profile analysis (TPA) is a very useful technique for researching food products, in which tenderness and elasticity (resilience) are the main texture properties of a food and related to quality (Psimouli and Oreopoulou, 2013).

The texture profile of tested canned meat samples were shown in Table (4), which involves hardness, adhesiveness, cohesiveness, springiness, gumminess and chewiness for canned meat which supplemented with taro mucilage, storage for six months even after two months at ambient temperature.

The hardness $(\mathrm{N})$ value of control sample was $51.90 \mathrm{~N}$ which increased in the samples treated with taro mucilage, which recorded $62.68,56.26$ and $53.92 \mathrm{~N}$ of treatments of $\mathrm{T}_{1}, \mathrm{~T}_{2}$ and $\mathrm{T}_{3}$, respectively. Also, from the same Table (4) cohesiveness value was higher in $\mathrm{T}_{1}(0.76)$ and $\mathrm{T}_{2}(0.70)$ than the control sample (0.67). On the other hand, springiness $(\mathrm{mm})$ value for samples containing taro mucilage(TM) was nearly to the control sample $(1.81 \mathrm{~mm})$, which was ranged from 1.43 to1.70 $\mathrm{mm}$ at zero time (Table 4). The same behavior was also observed in gumminess and chewiness properties of the tested samples even two months during the storage period (six months).

Also, Table (4) cleared that the texture profile of all tested samples was slightly decreased during storage period (six months) at ambient temperature, expect the two parameters (springiness and resilience). The addition of natural binder, antioxidant compounds can prevent the development of protein oxidation and maintain the textural properties of the canned meat at room temperature during storage period (six months) (Table4).

\section{Microbiological examination of canned meat supplemented with different levels of taro mucilage (TM) as compared by commercial gelatin (CG)}

The most important sources of microbial contamination of meat are endogenous sources, as the microbial load of meat is may be attributable to its high water activity, high protein content and approximately neutral $\mathrm{pH}$ (Yousuf et al., 2008 and Kumar et al., 2014).

The illustrated data in Table (5) showed that the mean value of total bacterial count of canned meat samples in control sample was $4.33 \times 10^{1}$ at zero time, while the total bacterial count of the samples treated with taro mucilage $\mathrm{T}_{1}, \mathrm{~T}_{2}$ and $\mathrm{T}_{3}$ was $3.66,3.42$ and $3 \times 10^{1}$; respectively. For the mould and yeast, total coliform bacterial counts, proteolytic bacterial counts and lipolytic bacterial of canned meat samples. Table (5) shows that there were no growth have been detected for all samples. Also, results given in Table (5) cleared that the total spore forming bacterial count (Clostridium and Bacillus) of the examined canned meat samples was not been detected of all samples.

The cause of reduced bacterial numbers may be due to the preparation of tested samples and 
heat treatment, which add some preservatives, especially nitrates, which play an important role in reducing the growth and inhibition of anaerobic bacteria, particularly Clostridium. Scientifically, the canning process took place, handling and transport are correctly carried out there was no contamination as reported by Alobaidi (2005). These results are relatively lower than that reported by Ebeed et al. (2015) reported that the level observed in canned beef with a mean value $2.96 \times 10^{-2}$.

Mohammed (2013) indicated that no significant difference was found in total aerobic bacteria, coliform bacteria, proteolytic bacteria, lipolytic bacteria, Bacillus and Clostridium, and he found that there were no growth have been indicated in canned chicken meat.

\section{Sensory evaluation of canned meat supplements with different levels of taro mucilage (TM) as compared by commercial gelatin (CG)}

The sensory panelists were recorded comparable color, flavor, texture, juiciness and palatability scores for canned meat which supplemented with taro mucilage which storage at room temperature for six months (Table 6). From tabulated data, score of color was 9.00 for control sample. While sample treated with taro mucilage $\mathrm{T}_{2}$ and $\mathrm{T}_{3}$ was recorded 8.90, which were slightly decrease compared to control sample at zero time. Table (6) cleared that score of color decreased in control sample during storage period compared to samples treated with taro mucilage. Furthermore, the highest color value was recorded in canned meat sample treated with taro mucilage during storage period (six months) at ambient temperature compared to control sample.

Color is one of the most important meat quality measures for consumers and can be changed and corrected with the use of additives and colorings (Skiepko et al., 2016).

Table (6) illustrated that the mean score of flavor was higher in sample treated with taro mucilage $\mathrm{T}_{1}$ (9.00) than control sample (8.90).From the same Table mean flavor scores followed a declining trend after four and six months compared to zero time and after two months. Flavor has been reported to be highly correlated to overall palatability, once tenderness is consider acceptable (Lucherk et al., 2016). Table (6) cleared that the control sample recorded the highest scores (8.90) for juiciness compared to the sample treated with taro mucilage $\mathrm{T}_{1}, \mathrm{~T}_{2}$ and $\mathrm{T}_{3}$ which was recorded $8.80,8.70$ and 8.50; respectively, at zero time.
As tabulated data it could be noticed that slightly decline in the sensory properties (juiciness) during storage period (six months) at ambient temperature, which scored from $9.00-$ 8.00. Juiciness is a sensory attribute which determined by consumer or trained sensory panels. Unlike other parameters of texture (e.g., tenderness), juiciness remains a uniquely subjective property of meat. In consumer grading systems, juiciness is estimated to contribute to $10 \%$ of the variation in overall acceptability of meat by a consumer (Watson et al., 2008).

The data in Table (6) showed that the mean texture scores followed a declining trend after six months compared to zero time. Also, the mean value of texture has been recorded the highest scores of $\mathrm{T}_{1}(8.90)$, and control sample (9.00) compared to the rest of treatments. The results in Table (6) are illustrated that the treatments control sample (8.95), and $\mathrm{T}_{1}$ (8.90) recorded the best palatability by panelist at zero time. On the other hand, there was decline in the sensory properties (palatability) scores in tested samples during storage period (six months) at room temperature, which ranged from 8.95 to 7.80. Palatability is defined as the overall eating experience surrounding a food product; in beef products, this usually focuses on tenderness, juiciness, and flavor, in addition to their interaction (Drey and O'Quinn, 2017).

\section{CONCLUSION}

The mucilage extracted from Colocasia esculenta will be useful as emulsifying agent in canned meat product contain high percentage of fat for improvement the texture profile and sensory properties. Addition of natural binder materials can prevent the development of protein oxidation of the canned meat at ambient temperature during storage period

\section{REFERENCES}

A.P.H.A. 1976. American Public Health Association, Compendium Methods for Microbiological Examination of Food. Sppeck. M.L., (Ed.); Washington, DC, U.S.A.

Al-Obaidi, D., 2005. Study Some Quality and Bacteriological Characters of Frozen and Canned Beef Imported to Iraq through 20032004. MSc Thesis, University of Baghdad, Iraq.

Andrade, L., Nunes, C., Pereira, J., 2015. Relationship between the chemical components of taro rhizome mucilage and its emulsifying property. J. Food Chem., 178, 331-338.

Arora, G., Malik, K., Singh, I., 2011. Formulation and evaluation of mucoadhesive matrix tablets 
of taro gum: optimization using response surface methodology. Polim. Med., 41 (2), 23-34.

Assi, O., Sidibe, D., Konan, Y., Coulibaly, A., Mahan, R., Biego, H., 2017. Viscosity study of mucilages extracted from Abelmoschus esculentus, Beilschmiedia mannii, Corchorus olitorius and Irvingia gabonensis from Côte d'Ivoire. J. Appl. Life Sci. Int., 11(1), 1-14.

Avallone, S., Brault, S., Mouquet, C., Trèche, S., 2003. Identification of the main food sources of iron, zinc and vitamin A in food consumption of the 1-to-5-year-old children of Ouarégou sanitary area (Burkina Faso). In: Food-based Approaches for a Healthy Nutrition in West Africa: The Role of Food Technologists and Nutritionists: Program and Abstracts. Universitaires de Ouagadougou Press, Burkina Faso, pp. 183-194.

Bourne, M.C., 2003. Bourne, M. C. (2002). Texture, viscosity, and food. In Food Texture and Viscosity (2nd ed.). New York, Academic Press.

Chau, C., Chueng, P., 1998. Functional properties of flours prepared from three Chinese indigenous legume seeds. Food Chem., 61 (4), 429-433.

Dickinson, E., 2003. Hydrocolloids at interfaces and the influence on the properties of dispersed systems. Food Hydrocol., 17 (1), 25-39.

Difco Laboratories Incorporated 1984. Difco manual culture media and reagent of dehydrated for microbiological and chemical laboratories. Inc, Detroit Michigan, USA.

Drey, L., O'Quinn, T., 2017. Tenderness, juiciness, and flavor contribute to the overall consumer beef eating experience. Kans. Agric. Experiment. Station Res. Rep., 3 (1), 27.

Duthie, G., Duthie, J., Kyle, J., 2000. Plant polyphenols in cancer and heart disease: implications as nutritional antioxidant. Nut. Res. Rev., 13, 79-106.

Ebeed, A., Elsayed E., Nabil M., Yasser G., Safaa, H., 2015. Quality assurance of imported canned meat. Global Vet., 14 (4), 511-516.

EOS., 2013. Egyptian Organization for Standardization and Quality Control. Egyptian Organization for Standardization and Quality Control. No. 3491 for Meat and Meat Products.

G.M.I.A., 2012. Gelatin Manufacturers Institute of America. Gelatin handbook. Gelatin Manufact. Inst.Am. New York, pp.1-25. [online], http://www.gelatingmia.com/html/qanda.html [retrieved: 22.09.2012].

Hamasalim, H., 2012. Quality assessment of the imported canned beef sold in Sulaimani markets. KSU J. Nat. Sci., 15 (4), 1-6.

Haug, I., Draget, K. 2009. Gelatin. In: G. O. Phillips \& P. A. Williams (Eds.), Handbook of Hydrocolloids, (2nd ed.): Woodhead Publishing Limited, Sawston, Cambridge, UK.
Hong, T., Ibrahim, H., 2012. Extraction and characterization pf mucilage from leaves of Pereskia bleo (rose cactus) J. Teknol. Dan. Indust. Pangan., 23 (2), 210-216.

John, M., 1999. Principles of Food Chemistry.3 ${ }^{\text {rd }}$ ed. Aspen Publishers Inc. New York, USA, Pp 27330.

Jones, J., Wolf, J., Mills, H., 1991. Plant analysis handbook: a practical sampling, preparation, analysis, and interpretation guide. Athens Ga: Micro-macro Publishing.

Kim, Y., Adeyemi, D., Korovulavula, P., Jang, D., Park, M., 2019. Effect of steaming on the functional compounds and antioxidant activity of Fijian taro (Colocasia esculenta L. Schott) corms. J. Food Preserv., 26 (4), 449-454.

Kumar, P., Rao, J., Haribabu, Y., Manjunath, D., 2014. Microbiological quality of meat collected from municipal slaughter houses and retail meat shops from Hyderabad Karnataka Region, India. APCBEE Procedia; 8, 364-369.

Lucherk, L., O'Quinn, T., Legako, J., Rathmann, R., Brooks, J., Miller, M., 2016. Consumer and trained panel evaluation of beef strip steaks of varying marbling and enhancement levels cooked to three degrees of doneness. Meat Sci.; 122, 145-154.

Matsuhiro, B., Lillo, L., Sáenz, C., Urzuá, C., Zárate, O., 2006. Chemical characterization of the mucilage from fruits of Opuntia Ficus indica. Carbohyd. Polym., 63 (2), 263-267.

Mohamed, A., Khalil, A., Hossam, E., 2010. Antioxidant and antimicrobial properties of kaff Maryam (Anastatica hierochuntica) and doum palm (Hyphaene thebaica). Grasas Y. Aceites, 61 (1), 67-75.

Mohammed, H., 2013. Study of some chemical, physical, sensory and bacteriology characteristics of canned chicken meat imported to Sulaymaniyah markets, Iraq. J. Int. Nut. Metabol., 5 (7), 128-133.

Nanjo, F., Goto, K., Sto, R., Suzuki, M., Sakai, M., Hara, Y. 1996. Scavenging effects of tea catechens and their derivatives on 1,1diphenyl-2-picrylydrazyl radical. Free Rad. Biol.Med.; 21: 895-902.

Naqvi, S., Khan, M., Shahid, M., Jaskani, M., Khan, I., Zuber, M., Zia, K., 2010. Biochemical profiling of mucilage extracted from seeds of different citrus rootstocks. J. Carbohyd. Polym. 83, 623-628.

Nguimbou, R., Boudjeko, T., Njintang, N., Himeda, M., Scher, J., Mbofung, C., 2012. Mucilage chemical profile and antioxidant properties of giant swamp taro tubers. J. Food Sci. Technol., 51 (12), 3559-3567.

Njintang, Y., Boudjeko,T., Tatsadjieu, N., NguemaOna, E., Scher, J., Mbofung, C., 2011. Compositional, spectroscopic and rheological 
analyses of mucilage isolated from taro (Colocasia esculenta L. Schott) corms. J. Food Sci. Technol., 51 (5), 900-907.

Obatolu, V., Fasoyiro, S., Ogunsunmi, L., 2001. Effect of processing on functional Properties of yam beans (Sphenostylis stenocarpa). J. Food Sci. Technol. Res., 7 (4), 319-322.

Oxoid, M., 1992. The Oxoid Manual of Culture Media and Other Laboratory Services. $5^{\text {th }}$, ed. Basingstock; Oxoid Hd.

Pharmacopoeia, B., 2008. The department of health, social services and public safety, council of Europe, Appendix XI E A273.

Raghavendra, S., Ramachandra, S., Rastogi, N., Raghavarao, K., Sourav, K., Tharanathan, R., 2006. Grinding characteristics and hydration properties of coconut residue: A source of dietary fiber. J. Food Engin., 72 (3), 281- 286.

Re, R., Pellegrini, N., Proteggente, A., Pannala, A., Yang, M., Rice- Evans, C., 1999. Antioxidant activity applying an improved ABTS radical cation de colorization assay. Free Radic. Biol. Med., 26, 1231-1237.

Sagou, S., 2008. Influence of metal cations on the physicochemical properties of functionalized carboxymethy 1-dextrane. Thesis, Institut National Polytechnique de Lorraine.;168.

Singleton, V., Orthoer, R., Lamula-Raventos, R. 1999. Analysis of total phenols and other oxidation substrates and antioxidant by mean o Folin-Ciocalteu reagent. Methods in Enzymology; 299: 152-178.

Skiepko, N., Chwastowska - Siwiecka, L., Kondratow, J., Mikulski, D. 2016. Effect of lycopene addition on the chemical composition, sensory attributes and physic chemical properties of steamed and grilled turkey breast. Brazillian J. Poultry Sci., 18 (2):319-330.
Skyberg, J., Rollins, M., Holderness, J., Marlenee, N., Schepetkin, I., Goodyear, A., Dow, S., Jutila, M., Pascual, D. 2012. Nasal Acai polysaccharides potentiate innate immunity to protect against pulmonary Francisellatularensis and Burkholderia pseudomallei infections. PLoS. Pathog; 8(3).

Smith, G., Carpenter, Z., Mittal, K., Cater, C. 1973 Efficacy of protein additives as emulsion stabilizer in by Faculty Agriculture Zagazig Univ., A.R.E.

Syamsu, J. 2007. Physical Characteristics of Feed Ducks in the Form of Pellets Given Different Adhesives and Different Storage Lengths. Animal Sci. J.; 7(2): 128-134.

Thanatcha, R., Pranee, A. 2011. Extraction and characterization of mucilage in Ziziphus mauritiana Lam. Int. Food Res. J.; 18(1): 201-212.

Thebaudin, J., Lefebvre, A., Harrington, M., Bourgeois, N. 1997. Dietary fiber; Nutritional and technology interest. Trends in Food Sci. Technol.; 8(2): 41-48.

USDA. 2003. United States Department of Agriculture.Purchases of grouned Beef Items frozen. Washington, DC. 250- 254.

Psimouli, V., Oreopoulou, V., 2013. The effect of fat replacers on batter and cake properties. J. food Sci., 78, 1495-1502.

Watson, R., Gee, A., Polkinghorne, R., Porter, M., 2008. Consumer assessment of eating quality development of protocols for Meat Standards Australia (MSA) testing. Aus. J. Exp. Agric., 48 (11), 1360-1367.

Yousuf, A., Ahmed, M., Yeasmin, S., Ahsan, N., Rahman, M., 2008. Prevalence of microbial load in shrimp, Penaeus monodon and Prawn, Macrobrachium rosenbergii from Bangladesh. World J. Agric. Sci., 4 (5), 852-855.

Table 1. Physical characteristics of taro mucilage and commercial gelatin.

\begin{tabular}{|c|c|c|c|c|}
\hline $\begin{array}{l}\text { Parameter } \\
\text { Samples }\end{array}$ & $\begin{array}{c}\text { Water } \\
\text { Absorption } \\
\text { (g water/g) }\end{array}$ & $\begin{array}{l}\text { Swelling } \\
\text { Index } \\
(\%)\end{array}$ & $\begin{array}{c}\text { Emulsion } \\
\text { Capacity (\%) }\end{array}$ & $\begin{array}{c}\text { Oil } \\
\text { Absorption } \\
\text { (g oil/g) }\end{array}$ \\
\hline \multicolumn{5}{|c|}{ Taro Mucilage (TM ) } \\
\hline $\mathrm{TM}_{1}$ & $23.48^{b c} \pm 0.7$ & $322 c \pm 2.9$ & $28.57^{b} \pm 0.05$ & $2.82^{\mathrm{a}} \pm 0.03$ \\
\hline $\mathrm{TM}_{2}$ & $24.28^{\mathrm{b}} \pm 0.1$ & $340^{\mathrm{b}} \pm 1.72$ & $35.71^{\mathrm{a}} \pm 0.04$ & $2.84^{\mathrm{a}} \pm 0.08$ \\
\hline $\mathrm{TM}_{3}$ & $23.20 \_ \pm 0.3$ & $317 \mathrm{~d} \pm 1.19$ & $27.14 c \pm 0.02$ & $2.24^{b} \pm 0.01$ \\
\hline \multicolumn{5}{|c|}{ Commercial Gelatin (CG) } \\
\hline CG & $37.80^{\mathrm{a}} \pm 0.4$ & $380^{\mathrm{a}} \pm 1.41$ & $14.28^{\mathrm{d}} \pm 0.03$ & $0.8^{c} \pm 0.05$ \\
\hline
\end{tabular}

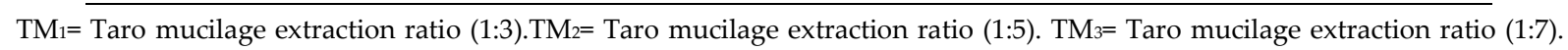
$\mathrm{CG}=$ Commercial gelatin. Reported values are the mean $\pm \mathrm{SD}$ of three replicates. Means in the same column followed by different lower case letters are significantly different $(p \leq 0.05)$. 
Table 2. Minerals Composition (mg/100g) of Taro Mucilage and Commercial Gelatin

\begin{tabular}{ccc}
\hline $\begin{array}{c}\text { Elements } \\
\text { sample }\end{array}$ & Taro Mucilage (TM) & $\begin{array}{c}\text { Commercial } \\
\text { Gelatin (CG) }\end{array}$ \\
\hline $\mathbf{N a}$ & (a) Macro Elements & \\
$\mathbf{C a}$ & 46.12 & 128.27 \\
$\mathbf{M g}$ & 84.30 & 602.50 \\
$\mathbf{K}$ & 54.10 & 127.70 \\
$\mathbf{P}$ & 36.50 & 15.62 \\
& 0.112 & 2.10 \\
$\mathbf{M n}$ & (b) Micro Elements & \\
$\mathbf{Z n}$ & 1.63 & 0.065 \\
$\mathbf{C d}$ & 2.53 & 15.12 \\
$\mathbf{P b}$ & $\mathrm{ND}$ & $\mathrm{ND}$ \\
& ND & ND \\
\hline
\end{tabular}

ND: not detected.

Table 3. Chemical quality attributes of canned meat supplemented with different levels of taro mucilage (TM) as compared to commercial gelatin (CG) during storage at ambient temperature for six months.

\begin{tabular}{|c|c|c|c|c|c|c|}
\hline Parameter & $\begin{array}{l}\text { Free Fatty } \\
\text { Acid } \\
\text { (FFA\%) }\end{array}$ & $\begin{array}{l}\text { Acid Value } \\
\quad(\mathrm{AV})\end{array}$ & $\begin{array}{c}\text { Peoxide Value } \\
\text { (P.V) } \\
\text { (meq.O'/Kg) }\end{array}$ & $\begin{array}{l}\text { Thiobarbtioric } \\
\text { Acid (TBA) (mg } \\
\text { malonaldhyde/k) }\end{array}$ & $\begin{array}{l}\text { Total volatile } \\
\text { nitrogen } \\
\text { (TVN } \\
\text { mg/100g) }\end{array}$ & $\mathrm{pH}$ \\
\hline Sampies & \multicolumn{6}{|c|}{ Zero Time } \\
\hline $\begin{array}{c}\text { Control } \\
\text { (Gelatin 3\%) }\end{array}$ & $0.065^{\mathrm{aA}} \pm 0.04$ & $0.129^{\mathrm{aA}} \pm 0.02$ & $0.52^{\mathrm{ab}} \pm 0.03$ & $0.271^{\mathrm{aa}} \pm 0.07$ & $3.72^{\mathrm{aA}_{ \pm} \pm 0.05}$ & $6.47^{\mathrm{aA}_{ \pm} \pm 0.6}$ \\
\hline$T_{1}$ & $0.042^{\mathrm{aA}} \pm 0.02$ & $0.084^{\mathrm{aA}} \pm 0.01$ & $0.39^{\mathrm{bA}} \pm 0.08$ & $0.183^{\mathrm{abA}} \pm 0.03$ & $3.54^{\mathrm{bB}} \pm 0.04$ & $6.52^{\mathrm{aA}} \pm 0.7$ \\
\hline$T_{2}$ & $0.038^{\mathrm{aA}} \pm 0.03$ & $0.075^{\mathrm{aA}} \pm 0.05$ & $0.32^{\mathrm{bcA}} \pm 0.09$ & $0.154^{\mathrm{bA}} \pm 0.06$ & $3.36^{\mathrm{CB}} \pm 0.08$ & $6.53^{\mathrm{aA}} \pm 0.2$ \\
\hline $\mathbf{T}_{3}$ & $0.033^{\mathrm{aA}} \pm 0.03$ & $0.065^{\mathrm{aA}} \pm 0.04$ & $\begin{array}{c}0.24^{\mathrm{c}} \pm 0.06 \\
\text { Two Month }\end{array}$ & $0.142^{\mathrm{bA}} \pm 0.01$ & $3.26^{\mathrm{dA} \pm 0.07}$ & $6.55^{\mathrm{aA} \pm 0.4}$ \\
\hline $\begin{array}{c}\text { Control } \\
\text { (Gelatin 3\%) }\end{array}$ & $0.067^{\mathrm{aA}} \pm 0.05$ & $0.133^{\mathrm{aA}} \pm 0.03$ & $0.54^{\mathrm{aAB}} \pm 0.06$ & $0.273^{\mathrm{aA}} \pm 0.08$ & $3.75^{\mathrm{aA}} \pm 0.09$ & $6.43^{\mathrm{aA}} \pm 0.4$ \\
\hline $\mathrm{T}_{1}$ & $0.043^{\mathrm{aA}} \pm 0.03$ & $0.085^{\mathrm{aA}} \pm 0.06$ & $0.40^{\mathrm{bA}} \pm 0.03$ & $0.184^{\mathrm{abA}} \pm 0.05$ & $3.58^{\mathrm{bB}} \pm 0.07$ & $6.50^{\mathrm{aA}} \pm 0.6$ \\
\hline$T_{2}$ & $0.039 \mathrm{aA} \pm 0.01$ & $0.077^{\mathrm{aA}} \pm 0.05$ & $0.32^{\mathrm{cA}} \pm 0.04$ & $0.155^{\mathrm{abA}} \pm 0.07$ & $3.39 \mathrm{CAB} \pm 0.02$ & $6.52^{\mathrm{aA}} \pm 0.8$ \\
\hline $\mathbf{T}_{3}$ & $0.035^{\mathrm{aA}} \pm 0.02$ & $0.069 \mathrm{aA} \pm 0.01$ & $\begin{array}{c}0.30^{\mathrm{c} A} \pm 0.01 \\
\text { Four Month }\end{array}$ & $0.144^{\mathrm{bA}} \pm 0.03$ & $3.24^{\mathrm{dA} \pm 0.06}$ & $6.53^{\mathrm{aA}} \pm 0.5$ \\
\hline $\begin{array}{c}\text { Control } \\
\text { (Gelatin 3\%) }\end{array}$ & $0.069^{\mathrm{aA}} \pm 0.05$ & $0.137^{\mathrm{aA}} \pm 0.08$ & $0.57^{\mathrm{aAB}} \pm 0.07$ & $0.277^{\mathrm{aA}} \pm 0.03$ & $3.79 \mathrm{aAB}_{ \pm} \pm 0.06$ & $6.40^{\mathrm{a}} \pm .02$ \\
\hline $\mathrm{T}_{1}$ & $0.046^{\mathrm{aA}} \pm 0.04$ & $0.091^{\mathrm{aA}} \pm 0.03$ & $0.45^{\mathrm{abA}} \pm 0.09$ & $0.188^{\mathrm{abA}} \pm 0.05$ & $3.63^{\mathrm{bAB}} \pm 0.02$ & $6.47^{\mathrm{aA}} \pm 0.7$ \\
\hline$T_{2}$ & $0.043^{\mathrm{aA}} \pm 0.01$ & $0.085^{\mathrm{aA}} \pm 0.04$ & $0.36^{\mathrm{bcA}} \pm 0.03$ & $0.161^{\mathrm{bA}} \pm \mathrm{C}$ & $3.44^{\mathrm{CAB}} \pm 0.05$ & $6.48^{\mathrm{aA}} \pm 0.9$ \\
\hline $\mathbf{T}_{3}$ & $0.039 \mathrm{aA}_{ \pm 0} 0.08$ & $0.077^{\mathrm{aA}} \pm 0.02$ & $\begin{array}{l}0.27^{\mathrm{CA}} \pm 0.05 \\
\text { Six Month }\end{array}$ & $0.150^{\mathrm{bA}} \pm 0.08$ & $3.28^{\mathrm{dA} \pm 0.03}$ & $6.50^{\mathrm{aA}} \pm 0.1$ \\
\hline $\begin{array}{c}\text { Control } \\
\text { (Gelatin 3\%) }\end{array}$ & $0.073^{\mathrm{aA}} \pm 0.05$ & $0.145^{\mathrm{aA} \pm 0.06}$ & $0.63^{\mathrm{aA}} \pm 0.03$ & $0.285^{\mathrm{aA}} \pm 0.07$ & $3.84^{\mathrm{aA}} \pm 0.02$ & $6.37^{\mathrm{aA}} \pm 0.1$ \\
\hline$T_{1}$ & $0.051^{\mathrm{aA}} \pm 0.02$ & $0.101^{\mathrm{aA}} \pm 0.03$ & $0.51^{\mathrm{bA} \pm 0.08}$ & $0.196^{\mathrm{bA}} \pm 0.04$ & $3.69 \mathrm{bA} \pm 0.06$ & $6.43^{\mathrm{aA}} \pm 0.3$ \\
\hline $\mathbf{T}_{2}$ & $0.048^{\mathrm{aA}} \pm 0 . .03$ & $0.095^{\mathrm{aA}} \pm 0.01$ & $0.40^{\mathrm{CA}} \pm 0.05$ & $0.167^{\mathrm{bA}} \pm 0.01$ & $3.50^{\mathrm{cA}} \pm 0.07$ & $6.45^{\mathrm{aA}} \pm 0.6$ \\
\hline $\mathbf{T}_{3}$ & $0.042^{\mathrm{aA}} \pm 0.04$ & $0.083^{\mathrm{aA}} \pm 0.05$ & $0.32^{\mathrm{cA}} \pm 0.07$ & $0.159^{\mathrm{bA}} \pm 0.03$ & $3.34 \mathrm{dA} \pm 0.05$ & $6.46^{\mathrm{aA}} \pm 0.8$ \\
\hline
\end{tabular}

Where: $\mathrm{T}_{1}=$ canned beef supported by $1 \%$ taro mucilage. $\mathrm{T}_{2}=$ canned beef supported by $2 \%$ taro mucilage. $\mathrm{T}_{3}=$ canned beef supported by $3 \%$ taro mucilage. Reported values are the mean \pm SD of three replicates. Means in the same column followed by different lower and capital case letters are significantly different $(\mathrm{p} \leq 0.05)$. 
Table 4. Texture profile of canned beef supplemented with different levels of taro mucilage (TM), as compared to commercial gelatin (CG), storage at ambient temperature for six months.

\begin{tabular}{|c|c|c|c|c|c|c|c|}
\hline $\begin{array}{c}\text { Parameter } \\
\text { Samples }\end{array}$ & $\begin{array}{l}\text { Hardness } \\
\text { (N) }\end{array}$ & $\begin{array}{c}\text { Adhesiveness } \\
\text { (N) }\end{array}$ & Cohesiveness & $\begin{array}{l}\text { Springiness } \\
\text { (mm) }\end{array}$ & Resilience & $\begin{array}{c}\text { Gumminess } \\
(\mathrm{N})\end{array}$ & $\begin{array}{l}\text { Chewiness } \\
\text { (MJ) }\end{array}$ \\
\hline \multicolumn{8}{|c|}{ Zero Time } \\
\hline $\begin{array}{c}\text { Control } \\
\text { Gelatin 3\% }\end{array}$ & 51.90 & 0.10 & 0.67 & 1.81 & 0.20 & 34.77 & 62.93 \\
\hline$T_{1}$ & 62.68 & 0.28 & 0.76 & 1.43 & 0.15 & 47.63 & 68.11 \\
\hline$T_{2}$ & 56.26 & 0.18 & 0.70 & 1.67 & 0.16 & 39.38 & 65.76 \\
\hline $\mathbf{T}_{3}$ & 53.92 & 0.17 & 0.67 & 1.70 & 0.20 & 36.12 & 61.40 \\
\hline \multicolumn{8}{|c|}{ Two Months } \\
\hline $\begin{array}{c}\text { Control } \\
\text { Gelatin 3\% }\end{array}$ & 50.74 & 0.10 & 0.65 & 1.86 & 0.21 & 32.98 & 61.34 \\
\hline$T_{1}$ & 62.18 & 0.20 & 0.73 & 1.50 & 0.16 & 45.39 & 68.09 \\
\hline$T_{2}$ & 55.46 & 0.17 & 0.68 & 1.71 & 0.18 & 37.71 & 64.48 \\
\hline $\mathbf{T}_{3}$ & 51.92 & 0.16 & 0.66 & 1.79 & 0.20 & 34.26 & 61.32 \\
\hline \multicolumn{8}{|c|}{ Four Months } \\
\hline $\begin{array}{c}\text { Control } \\
\text { Gelatin 3\% }\end{array}$ & 47.94 & 0.09 & 0.63 & 1.97 & 0.23 & 30.20 & 59.49 \\
\hline$T_{1}$ & 58.20 & 0.18 & 0.71 & 1.54 & 0.19 & 41.32 & 63.64 \\
\hline$T_{2}$ & 52.05 & 0.13 & 0.68 & 1.74 & 0.20 & 35.39 & 61.57 \\
\hline $\mathrm{T}_{3}$ & 48.11 & 0.12 & 0.65 & 1.81 & 0.23 & 31.27 & 56.59 \\
\hline \multicolumn{8}{|c|}{ Six Months } \\
\hline $\begin{array}{c}\text { Control } \\
\text { Gelatin 3\% }\end{array}$ & 43.92 & 0.07 & 0.59 & 1.98 & 0.26 & 25.91 & 51.30 \\
\hline $\mathrm{T}_{1}$ & 54.87 & 0.16 & 0.66 & 1.55 & 0.22 & 36.21 & 56.12 \\
\hline$T_{2}$ & 48.19 & 0.11 & 0.63 & 1.78 & 0.23 & 30.35 & 54.02 \\
\hline$T_{3}$ & 42.93 & 0.10 & 0.60 & 1.83 & 0.25 & 25.75 & 47.12 \\
\hline
\end{tabular}

Where: $T_{1}=$ canned beef supported by $1 \%$ taro mucilage. $T_{2}=$ canned beef supported by $2 \%$ taro mucilage. $T_{3}=$ canned beef supported by $3 \%$ taro mucilage.

Table 5. Microbiological analysis of canned beef supplemented with different levels of taro mucilage (TM), as compared to commercial gelatin (CG)

\begin{tabular}{cccccccc}
\hline Parameter & $\begin{array}{c}\text { Total } \\
\text { Viable } \\
\text { bacterial } \\
\text { count }\end{array}$ & $\begin{array}{c}\text { Mould } \\
\text { and } \\
\text { Yeast }\end{array}$ & $\begin{array}{c}\text { Total } \\
\text { Colifrom } \\
\text { Bacterial } \\
\text { Count }\end{array}$ & $\begin{array}{c}\text { Proteolytic } \\
\text { Bacteria } \\
\text { Count }\end{array}$ & $\begin{array}{c}\text { Lipolytic } \\
\text { Bacterial } \\
\text { Count }\end{array}$ & $\begin{array}{c}\text { Total Spore } \\
\text { Forming } \\
\text { Bacterial } \\
\text { Bacillus (sp.) }\end{array}$ & $\begin{array}{c}\text { Total Spore } \\
\text { Forming } \\
\text { Bacterial } \\
\text { Clostridum (sp.) }\end{array}$ \\
\hline $\begin{array}{c}\text { Control } \\
\text { (Gelatin }\end{array}$ & $4.33 \times 10^{-1}$ & N.D & N.D & N.D & N.D & N.D & N.D \\
$\mathbf{3 \% )}$ & & & & & & & \\
$\mathbf{T}_{1}$ & $3.66 \times 10^{-1}$ & N.D & N.D & N.D & N.D & N.D & N.D \\
$\mathbf{T}_{2}$ & $3.42 \times 10^{-1}$ & N.D & N.D & N.D & N.D & N.D & N.D \\
$\mathbf{T}_{3}$ & $3 \times 10^{-1}$ & N.D & N.D & N.D & N.D & N.D & N.D \\
\hline
\end{tabular}

Where: $\mathrm{T}_{1}=$ canned beef supported by $1 \%$ taro mucilage. $\mathrm{T}_{2}=$ canned beef supported by $2 \%$ taro mucilage. $\mathrm{T}_{3}=$ canned beef supported by $3 \%$ taro mucilage. 
Table 6. Sensory evaluation of canned beef supplemented with different levels of taro mucilage (TM) as compared to commercial gelatin (CG) during storage at room temperature for six months.

\begin{tabular}{|c|c|c|c|c|c|}
\hline Parameter & Color & Flavor & Juiciness & Texture & Palatability \\
\hline Samples & \multicolumn{5}{|c|}{ Zero Time } \\
\hline $\begin{array}{c}\text { Control (Gelatin } \\
3 \% \text { ) }\end{array}$ & $9.00^{\mathrm{aA}} \pm 0.5$ & $8.90^{\mathrm{aA}} \pm 0.2$ & $8.90^{\mathrm{aA}} \pm 0.8$ & $9.00^{\mathrm{aA}} \pm 0.1$ & $8.95^{\mathrm{aA}} \pm 0.6$ \\
\hline $\mathrm{T}_{1}$ & $9.00^{\mathrm{aA}} \pm 0.3$ & $9.00^{\mathrm{aA}} \pm 0.9$ & $8.80^{\mathrm{aA}} \pm 0.4$ & $8.90^{\mathrm{aA}} \pm 0.5$ & $8.90^{\mathrm{aA}} \pm 0.9$ \\
\hline $\mathbf{T}_{2}$ & $8.90^{\mathrm{aA}} \pm 0.7$ & $8.80^{\mathrm{aA}} \pm 0.1$ & $8.70^{\mathrm{aA}} \pm 0.6$ & $8.70^{\mathrm{aA}} \pm 0.3$ & $8.70^{\mathrm{aA}} \pm 0.4$ \\
\hline \multirow[t]{2}{*}{$\mathrm{T}_{3}$} & $8.90^{\mathrm{aA}} \pm 0.6$ & $8.50^{\mathrm{adA}} \pm 0.3$ & $8.50^{\mathrm{aA}} \pm 0.1$ & $8.50^{\mathrm{aA}} \pm 0.7$ & $8.50^{\mathrm{aA}} \pm 0.2$ \\
\hline & \multicolumn{4}{|c|}{ Two Month } & \\
\hline $\begin{array}{c}\text { Control (Gelatin } \\
3 \% \text { ) }\end{array}$ & $8.70^{\mathrm{aA}} \pm 0.4$ & $8.80^{\mathrm{aA}} \pm 0.8$ & $8.80^{\mathrm{aA}} \pm 0.7$ & $8.90^{\mathrm{aA}} \pm 0.2$ & $8.92^{\mathrm{aA}} \pm 0.1$ \\
\hline $\mathbf{T}_{1}$ & $8.80^{\mathrm{aA}} \pm 0.9$ & $8.90^{\mathrm{aA}} \pm 0.7$ & $8.80^{\mathrm{aA}} \pm 0.2$ & $8.80^{\mathrm{aA}} \pm 0.8$ & $8.90^{\mathrm{aA}} \pm 0.3$ \\
\hline $\mathbf{T}_{2}$ & $8.80^{\mathrm{aA}} \pm 0.1$ & $8.70^{\mathrm{aA}} \pm 0.3$ & $8.60^{\mathrm{aA}} \pm 0.9$ & $8.60^{\mathrm{aA}} \pm 0.5$ & $8.62^{\mathrm{aA}} \pm 0.7$ \\
\hline \multirow[t]{2}{*}{$\mathrm{T}_{3}$} & $8.90 \mathrm{aA} \pm 0.5$ & $8.30^{\mathrm{aA}} \pm 0.6$ & $8.50 \mathrm{aA} \pm 0.3$ & $8.50 \mathrm{aA} \pm 0.1$ & $8.47 \mathrm{aA} \pm 0.4$ \\
\hline & \multicolumn{4}{|c|}{ Four Month } & \\
\hline $\begin{array}{c}\text { Control (Gelatin } \\
3 \% \text { ) }\end{array}$ & $7.80^{\mathrm{aB}} \pm 0.3$ & $8.70^{\mathrm{aA}} \pm 0.9$ & $8.70^{\mathrm{aA}} \pm 0.4$ & $8.70^{\mathrm{aA}} \pm 0.6$ & $8.82^{\mathrm{aA}} \pm 0.5$ \\
\hline $\mathbf{T}_{1}$ & $8.60^{\mathrm{aA}} \pm 0.8$ & $8.70^{\mathrm{aA} \pm 0.1}$ & $8.60^{\mathrm{aA}} \pm 0.6$ & $8.70^{\mathrm{aA} \pm 0.9}$ & $8.80^{\mathrm{aA}} \pm 0.2$ \\
\hline $\mathbf{T}_{2}$ & $8.70^{\mathrm{aA}} \pm 0.5$ & $8.50^{\mathrm{abA}} \pm 0.3$ & $8.50^{\mathrm{aA}} \pm 0.9$ & $8.30^{\mathrm{aAB}} \pm 0.2$ & $8.50^{\mathrm{aA}} \pm 0.7$ \\
\hline \multirow[t]{2}{*}{$\mathbf{T}_{3}$} & $8.80^{\mathrm{aA}} \pm 0.2$ & $8.00^{\mathrm{abA}} \pm 0.6$ & $8.30^{\mathrm{aA}} \pm 0.1$ & $8.00^{\mathrm{aA}} \pm 0.1$ & $8.35^{\mathrm{aA}} \pm 0.8$ \\
\hline & \multicolumn{4}{|c|}{ Six Month } & \\
\hline $\begin{array}{c}\text { Control (Gelatin } \\
3 \% \text { ) }\end{array}$ & $7.20^{\mathrm{bB}} \pm 0.6$ & $8.50^{\mathrm{aA}} \pm 0.4$ & $8.50^{\mathrm{aA}} \pm 0.7$ & $8.40^{\mathrm{aA}} \pm 0.3$ & $8.74^{\mathrm{aA}} \pm 0.1$ \\
\hline $\mathbf{T}_{1}$ & $8.30^{\mathrm{aA}} \pm 0.1$ & $8.40^{\mathrm{aA}} \pm 0.8$ & $8.30^{\mathrm{aA}} \pm 0.2$ & $8.30^{\mathrm{aA}} \pm 0.7$ & $8.65^{\mathrm{aA}} \pm 0.6$ \\
\hline $\mathbf{T}_{2}$ & $8.50^{\mathrm{aA}} \pm 0.3$ & $8.20^{\mathrm{aA}} \pm 0.6$ & $8.20^{\mathrm{aA}} \pm 0.1$ & $7.90^{\mathrm{aB}} \pm 0.2$ & $8.22^{\mathrm{aA}} \pm 0.5$ \\
\hline $\mathbf{T}_{3}$ & $8.70 \mathrm{aA} \pm 0.5$ & $7.90 \mathrm{aA} \pm 0.2$ & $8.00 \mathrm{aA} \pm 0.9$ & $7.70^{\mathrm{aA}} \pm 0.4$ & $7.95^{\mathrm{aA}} \pm 0.3$ \\
\hline
\end{tabular}

Note: $\mathrm{T}_{1}=$ canned beef supported by $1 \%$ taro mucilage. $\mathrm{T}_{2}=$ canned beef supported by $2 \%$ taro mucilage. $\mathrm{T}_{3}=$ canned beef supported by $3 \%$ taro mucilage. Reported values are the mean \pm SD of three replicates. Means in the same column followed by different lower and capital case letters are significantly different $(p \leq 0.05)$.

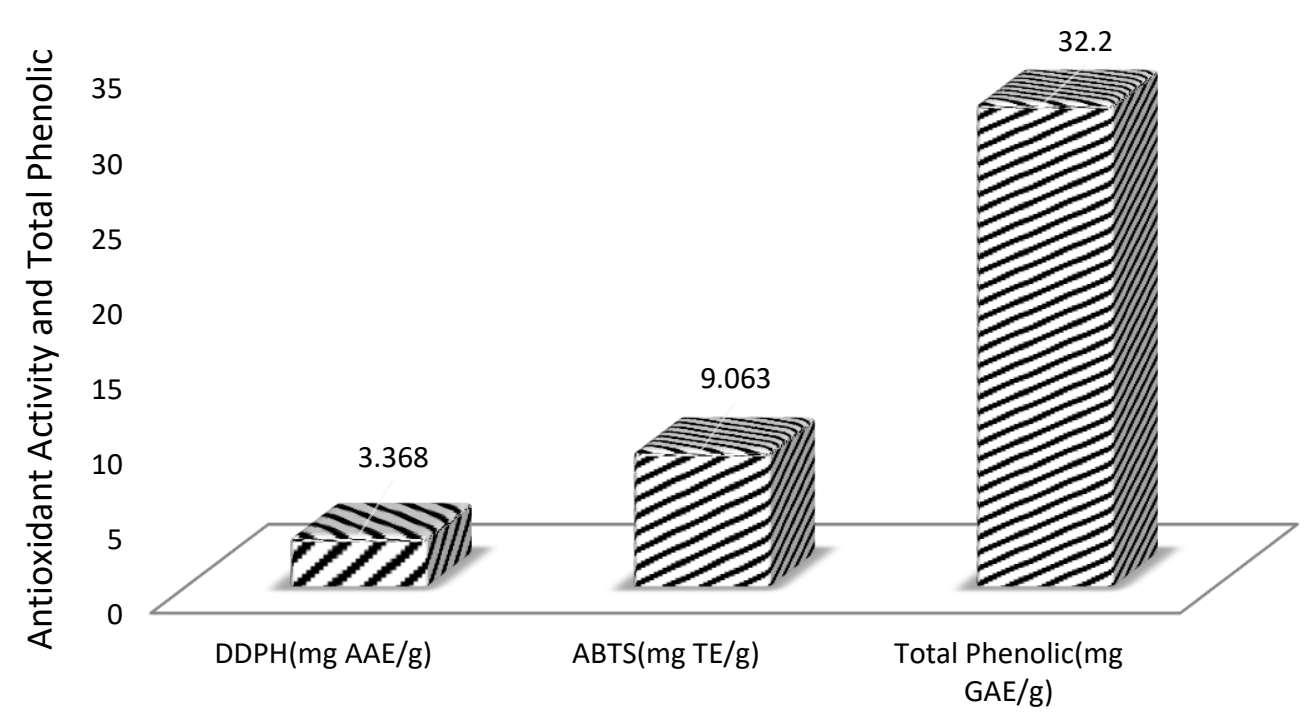

Taro mucilage

Figure 1. Antioxidant activity and total phenolic content of taro mucilage. 


\section{استخدام الموسيلاج المستخلص من درنات القلقاس (Colocasia esculenta) في اللحم البقري الملبلب}

$$
\begin{aligned}
& \text { شياء عبد المحيد حذيفة "، سعاد محمود الدسوقي، رباب حسن سالم }
\end{aligned}
$$

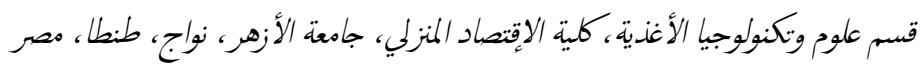

"البريد الككترونى للباحث الرئيس: shaymaaabdelhamedhozifa@azhar.edu.eg

$$
\text { الملخص العريي }
$$

بعض الدول الهسلامية ترفض الجيلاتين التجاري لأن بعض الدول تقوم بتصنيعه من المنازير مما أدى إلي البحث عن بدائل للجيلاتينين من مصادر نباتية.

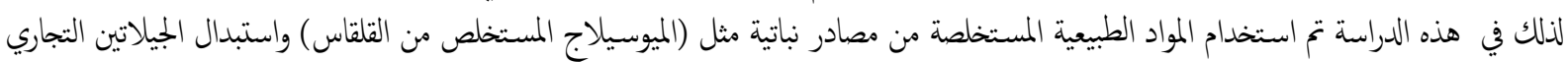

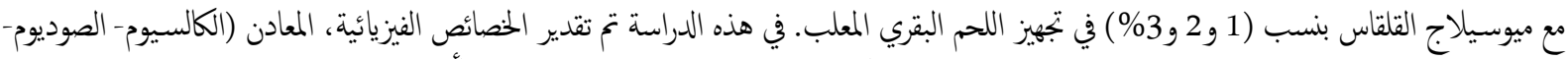

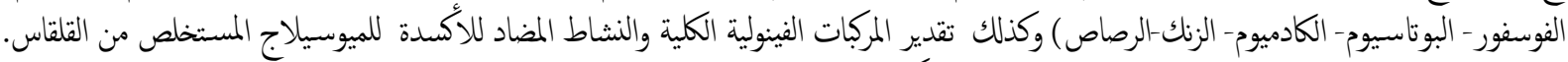

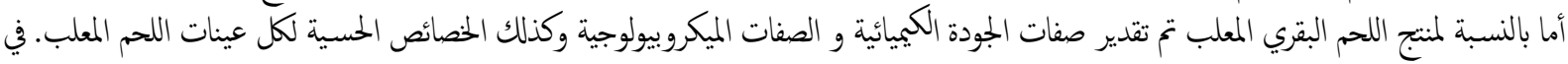

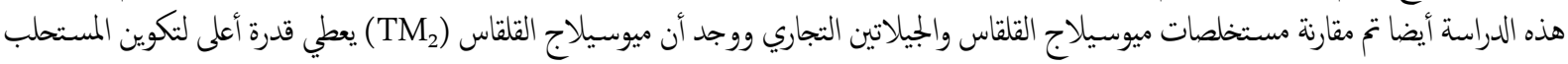

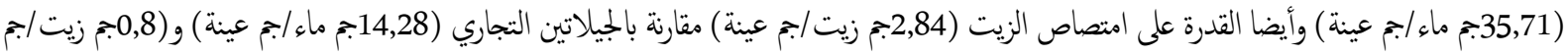

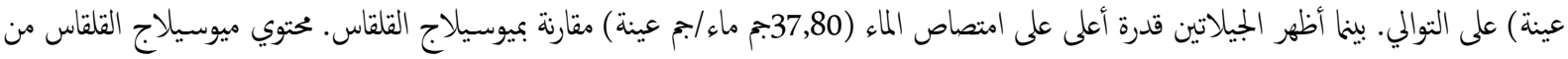

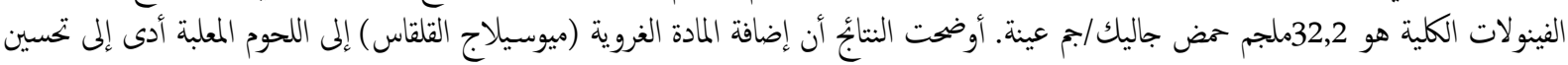

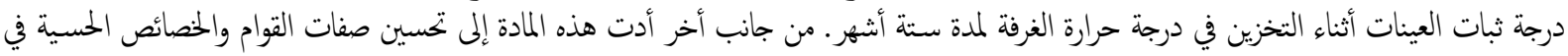
عينات اللحم البقري المعلب. الكلمات الاسترشادية: ميوسيلاج القلقاس، صفات القوام، خصائص الجودة، منتجات اللحوم. لمعبر. 